\title{
THE PERCEPTION OF LEGAL RISK AND ITS IMPACT ON THE BUSINESS OF SMES
}

\author{
Zuzana Virglerová \\ Tomas Bata University in Zlín, Faculty of Management and Economics, Zlín, Czech Republic \\ Email: virglerova@utb.cz \\ Francesca Conte \\ University of Salerno, Department of Political and Communication Sciences, Fisciano, Italy \\ Email: fconte@unisa.it \\ John Amoah \\ Tomas Bata University in Zlín, Faculty of Management and Economics, Zlín, Czech Republic \\ Email: \\ Maria Rita Massaro \\ University of Westminster, School of Management and Marketing, London, UK \\ Email: r.massaro@westminster.ac.uk
}

Received: 15 October 2020. Revision received: 28 November 2020. Accepted: 14 December 2020

\begin{abstract}
One of the prerequisites for a favourable business environment is a stable legislative context and law enforcement. In particular, for SMEs, that do not have the financial resources for stable legal assistance, legal risk is becoming one of the most important business risks. This paper aims to enrich the current scientific knowledge compared to the impact of legal risk on SMEs in selected countries. Tomas Bata University conducted empirical research in Zlín during 2019-2020. In total, 1935 SMEs completed the questionnaire, and their responses were examined to fulfill the paper's purpose. The four statistical hypotheses were analysed through statistical methods such as Z-score and Chi-square tests, with IBM SPSS Statistics 23.0 used for data evaluation. Findings highlight that more than $50 \%$ of SMEs consider the management of legal risk as appropriate. Only 39\% of SMEs consider the business environment as over-regulated. Almost 50\% of entrepreneurs agree that their business is affected by frequent legislative changes but with no negative impact. There are statistically significant differences in consideration of legal risk between SMEs from the Czech Republic and the rest of the selected countries (Slovakia, Poland, Hungary, and Ukraine). This paper's practical implication would help SMEs in V4 Countries, Ukraine, and other SME players to fully understand legal risk and allow them to create appropriate policies that will ensure fewer negative impacts of risks.
\end{abstract}

KEYWORDS: Entrepreneurship, small and medium enterprises, business risk, legal risk

JEL CLASSIFICATION: K22, L26, M21

Reference: Virglerova, Z., Conte, F., Amoah, J., \& Massaro, M. R. (2020). The Perception of Legal Risk and Its Impact on the Business of SMEs. International Journal of Entrepreneurial Knowledge, 8(2), 1-13. doi: 10.37335/ijek.v8i2.115

\section{INTRODUCTION}

Small and medium enterprises (SMEs) have become a fundamental source of positive business development in both developed and developing countries, including the Visegrad Group (V4 Countries; Poland, Czechia, Slovakia and Hungary) and Ukraine (Pasnicu, 2018). SMEs operate in a complex environment without the benefits of adequate capital and extensive human resources of the largest organizations (Watkins, 2012). Thus, due to their smaller set of both financial and non-financial resources, SMEs are relatively more vulnerable to business risks compared to larger enterprises (Falkner \& Hiebl, 2015). In the context of the business risks that the company may incur, legal risk is defined extensively as the result of damages or losses suffered to a particular business or firm due to its negligence 


\section{INTERNATIONAL JOURNAL OF ENTREPRENEURIAL KNOWLEDGE}

Issue 2, volume 8, ISSN 2336-2960 (Online)

www.ijek.org

in compliance with laws related to a particular business in nature. It is mostly encountered at the either early or final stage of the business proceedings (Kwaku Amoah, 2018; Wang et al., 2016; Cook \& Nixson, 2000; Ghența \& Matei, 2018; Ruchkina et al., 2017). However, SMEs are exposed to four types of risk namely operational, financial, strategic, and hazardous or pure risk (Belas et al., 2019; Cepel et al, 2019). The literature highlighted that ability to handle legal risk allows firms to better achieve their goals which ensures long term viability (Ferreira de Araújo Lima et al., 2020). SMEs are therefore admonished to embrace legal risk in their strategic plans.

SMEs in recent times have experienced uncertainty in businesses leading to exposure to factors such as legal risk. Although SMEs in V4 Countries and Ukraine are well noted for their positive economic contributions (which are well documented in the literature and European journals, e.g. Mura \& Ključnikov, 2018; Antoniuk et al., 2018), they are intermittently faced with legal risk from the growing global marketplace and the impact of customers' demands. Limited research has been conducted in this area which is a driver for this current study to be conducted. In this paper, we will compare the impacts of legal risk on the SMEs in the selected countries. The differences between the Czech Republic and other countries (Hungary, Poland, Slovakia, Ukraine) are analysed. These countries are noted for similarities in history, economic development, and political ideologies. The practical implication of this paper would help SMEs in V4 Countries, Ukraine, and other SME players to fully understand legal risk and will allow them to create appropriate policies that will ensure less negative impacts on them. Likewise, from a theoretical point of view, the paper contributes to fill the existing gap and enriches the current knowledges about risk management. The research question which will fulfil the aim of the paper is as follows: What are the similarities and differences in perception of legal risk between entrepreneurs from Czech SMEs and entrepreneurs from other selected countries?

The paper is organized as follows; section one introduces the paper, followed by section two which reveals the key literature reviewed. The other sections contain the methodology and sources of data for the empirical analysis of legal risk and SMEs in V4 countries and Ukraine, results, discussions and conclusions.

\section{LITERATURE REVIEW}

\subsection{Legal Environmental and Business of SMEs}

Legal risk is an essential factor that small and medium enterprises (SMEs) cannot ignore in doing business in postmodern times. When the legal risk is appropriately adhered to, SMEs easily achieve good financial performances and avoid additional costs, such as fines and punitive damages, that eventually reduce the profitability and also jeopardize the firm (Deligonul, 2020; Bagley, 2008). Reverte (2015) established that SMEs can enjoy sustainability in business when legal risks are embraced by them and create a sound environment for business or operations. Shanmugam (2010) states that risk is an integral element of negative exposure in business operations or transactions. Moreover, Pereira et al. (2015) also established a linkage between legal risk and SMEs in V4 Countries and Ukraine since their involvement in the markets is always in abundance. Inherently, SMEs in V4 Countries and Ukraine are exposed to legal risk since they are key players on the market, hence direct business effect can be seen when failure of legal risk is assumed. The adoption of legal risk by SMEs in the Czech Republic and V4 Countries facilitates the process of using loans and other credit facilities from both financial institutions and European communities hence creating the healthy business environment (Gwizdała, 2017; Bondareva \& Zatrochová, 2014). However, Zhao and Zeng, (2014) describe risk as a circumstance resulting in unwanted or negative performance which eventually affects the firm.

\subsection{Effect of Legal Risk/Legislative Changes}




\section{INTERNATIONAL JOURNAL OF ENTREPRENEURIAL KNOWLEDGE}

Issue 2, volume 8, ISSN 2336-2960 (Online)

www.ijek.org

Frequent changes in the business environment usually affect SMEs depending on how SMEs embrace them (Dvorský et al., 2020; Karpak \& Topçu, 2010). Also, Zhao \& Zeng, (2014) reveal that when legal risk in not appropriately managed, SMEs in V4 Countries and Ukraine would experience negative reportage in their businesses. SMEs in the V4 Countries and Ukraine have always been exposed to constant demands of new products and services, hence the legal risk for SMEs in these countries is relevant (Faisal \& Singh, 2019). Similarly, Ruchkina et al. (2017) reveal that frequent legislative changes by government fiscal policy and other legal institutions relating to SME operations foster its growth and development. Also, SMEs in the Czech Republic and other V4 Countries are usually confronted with legislative changes but subsequently complied with the law requirements (Wysokinska, 2017). Ironically, such legislative changes are often initiated to balance the interest of both regulators and SMEs. These changes can include capital requirements, environment monitoring, and control, tax and audit compliance, etc.

Pasnicu (2018) in a study about supporting SMEs in creating jobs brought to light that SMEs are often faced with legislative changes from government and other controlling bodies in the Czech Republic and V4 Countries, not in a negative way, but for their growth and development. This is based on their numerous contributions to the economic development of their operations and to promote entrepreneurship, better regulation, access to finance and access to markets, and internationalization. An investigation made by Grau and Reig (2020) stated that although SMEs experience changes in legislation, they can still cope with such policies which then strengthens them for further operations. In examining this, SMEs ensure that such changes do not harm their sustainability in terms of its profitability, operations, and investments.

\subsection{Business Environment}

The business environment is always considered to be a key factor in SME's growth and development concerning legal risk. The business environment connotes the external forces, factors, and institutions that are beyond the control of the business and usually affect the functionality of a business enterprise. Such factors include customers, competitors, suppliers, government (legal, social, political), and technological factors. According to Virglerova et al. (2016), the conditions of the business environment play a vital role in the SME framework. Their study revealed that the Czech Republic legal framework is seen to be favourable for SME's smooth running with $62.49 \%$ of participants agreeing that the legal risk framework favours the SME's role. Furthermore, Bondareva and Zatrochová (2014) also conclude that the smooth operations of the legal risk framework in the business environment provide a stable and successful market for SMEs to leverage on for its development. The business environment is not overregulated by legal risk. This makes it possible for SMEs in the Czech Republic and V4 Countries to fully assume economic growth and internalization and hence increase the competitiveness of SME's products on international markets. The legal risk framework has also provided an increase in the productivity of SMEs in the Czech Republic and V4 Countries (Kotaskova \& Rozsa, 2018). Thus, over-regulations of the legal risk of SMEs do not affect the business environment in the Czech Republic and V4 Countries but rather help SMEs for better expansions. Kim \& Vonortas (2014) suggest that SMEs usually find business environment not to be over-regulated in terms of legal risk but rather attached much significance to it since such risk inherently supports the sustainability of their operations.

\section{$1.4 \quad$ Importance of Legal Risk}

SMEs usually operate in a very competitive market that requires much adherence to legal risk. Understanding or attaching importance to legal risk helps SMEs in doing business and also prevents firms from collapse (Petković et al., (2016). The link between legal risk and entrepreneurship of SMEs has been investigated but a significant research gap remains when considering the relationship between 
INTERNATIONAL JOURNAL OF ENTREPRENEURIAL KNOWLEDGE

Issue 2, volume 8, ISSN 2336-2960 (Online)

www.ijek.org

them. Similarly, understanding the essentials of doing business in a legal risk context helps SMEs in the Czech Republic and V4 Countries to adequately develop an interest for innovations, increase firms performance, and shapes the organizational structures of SMEs (Martinez-Conesa et al., 2017; PalaciosMarqués et al., 2015). In extensive research by Bàcsi \& Herczeg (2014), findings reveal that understanding the legal risk procedures usually sustains SMEs in the Czech Republic and V4 Countries to significantly create more socio-economic development in the countries involved. The study also states that legal risk strengthens the administrative environment which enhances the activity of the SMEs. However, SMEs in the Czech Republic and V4 Countries exist in a competitive market (with respect to products and services) which calls for strict adherence to legal risk (Ferreira de Araújo Lima et al., 2020). Understanding such a legal aspect always offers a monumental challenge to SMEs found in these countries. The key role of SMEs in V4 countries presupposes that effective risk management is an essential aspect for sustainability of economic growth.

\section{METHODOLOGY AND DATA SOURCE}

The aim of this paper is to compare the impact of legal risk on the SMEs in the selected countries. The differences between Czech Republic and other countries (Hungary, Poland, Slovakia, Ukraine) are analysed. In order to achieve the purpose of the study, we exploited an exploratory approach through a structured questionnaire. An exploratory research design, including a survey, is a common approach in social and economic sciences (Sarantakos, 2005).

Empirical research was conducted from September 2019 to April 2020 and the unit of analysis includes SMEs belonging to the V4 countries, Czech Republic (CR), Slovak Republic (SR), Poland (PL), Hungary $(\mathrm{H})$ and Ukraine(UA). We randomly selected 8,250 SMEs in CR, 10,100 SMEs in SR, 7,680 SMEs in PL, 8,750 SMEs in $\mathrm{H}$ and more than 5,500 SMEs in UA. The average rate of return of the questionnaires was as follows: CR - 3.6\%; SR - 5.5\%, PL - 4.7\%, H - 4.6\% and UA - 6.4\%.

The research was carried out by the Faculty of Management and Economics of the Tomas Bata University in Zlin in cooperation with the University of Business and Law in Prague; Faculty of Economics and Business of the Pan-European University in Bratislava and the Faculty of Socio-Economic Relations, the Alexander Dubcek University in Trencin.

A total of 1935 firms responded to the survey. They are subdivided considering the nationality: 454 respondents from the Czech Republic, 368 respondents from the Slovak Republic, 364 respondents from Poland, 399 respondents from Hungary and 350 respondents from Ukraine.

In the Czech Republic, the structure of SMEs was as follows: 107 (23.6\%) small enterprise (from 10 to 49 employees), 290 (63.9\%) micro-enterprise (up to 9 employees), 57 (12.5\%) medium-sized enterprise (from 50 to 249 employees). In Slovakia: 106 (28.8\%) small enterprise, $216(58.7 \%)$ micro enterprise, 46 $(12.5 \%)$ medium enterprise. In Poland: 85 (23.3\%) small enterprise, 202 (55.5\%) micro enterprise, 77 (21.2\%) medium enterprise. In Hungary: 268 (67.2\%) micro-enterprise, 131 (32.8\%) medium-sized enterprise. In Ukraine: 105 (30.0\%) small enterprise, 163 (46.6\%), 82 (23.4\%) medium-sized enterprise.

In the paper, the following statements are analysed:

ST1: I consider the legal risk-appropriate and it does not harm our (my) business.

ST2: Business is affected by frequent legislative changes, but it has no negative impact on our (my) business.

ST3: I do not consider the business environment to be 'over-regulated'.

ST4: I understand the essential legal aspects of doing business. 
INTERNATIONAL JOURNAL OF ENTREPRENEURIAL KNOWLEDGE

Issue 2, volume 8, ISSN 2336-2960 (Online)

www.ijek.org

Respondents could choose one of five options to answer: strongly agree, agree, neither agree nor disagree, disagree or strongly disagree.

The following hypotheses were created to fulfil the aim of the paper:

H1: There are statistically significant differences in perception of legal risk between entrepreneurs from Czech SMEs and entrepreneurs from other countries.

H2: There are statistically significant differences in perception of legislative changes and their impact on SMEs between Czech entrepreneurs and entrepreneurs from other countries.

H3: There are statistically significant differences in perception of the quantity of regulation between Czech entrepreneurs and entrepreneurs from other countries.

H4: There are statistically significant differences in understanding of the essential legal aspects of doing business between Czech entrepreneurs and entrepreneurs from other countries.

Statistical methods such as Pearson's Chi-square test and Z-score were applied to evaluate the formulated statistical hypotheses. Testing of statistical hypotheses was performed using the following consecutive steps: a) formulation of null statistical hypotheses, b) selection of the test criterion (hereinafter TC), c) calculation of TC, d) determination of the critical area of testing, e) decision to reject null statistical hypotheses, f) interpretation of achieved results.

Statistical methods of Pearson's Chi-square test and Z-score at the significance limit of 0.05 were applied to determine statistically significant differences between selected groups of respondents according to selected criteria. These methods are mainly used to detect statistical differences between two or more sample groups in several areas of the economy. All necessary calculations were performed using statistical software SPSS Statistics v23 and MS Excel.

\section{RESULTS AND DISCUSSION}

The research results are shown in the following tables.

The agreement with ST1 claims ranges from 34.06\% (Poland: lowest agreement rate) to $81.43 \%$ (Ukraine: highest agreement rate). The average rate of agreement with ST1 was $51.37 \%$. This result corresponds to statements made by Deligonul (2020). He confirms that the appropriate management of legal risk brings efficiency to the whole system. Firms that manage the legal risk correctly do not need to pay the penalty, and the business is more sustainable. Moreover, if the organization properly complies with legislative regulations, it is considered by the stakeholders with whom it relates' as a reliable and credible company. This has a positive impact on the perception of public opinion and, consequently, improves the reputational capital of the organization. In this perspective, SMEs benefit from an intangible asset that is fundamental for achieving competitive advantage and competing in a complex business environment (Abimbola \& Vallaster, 2007).

Based on the use of the Chi-square method, we found that the responses of Czech entrepreneurs differ from the attitudes of Slovak, Polish, Hungarian and Ukrainian entrepreneurs ( $\mathrm{p}$-value $=0.0018 /<0.0001$ $/<0.0001 /<0.0001)$.

The Z-score test values confirmed that there are statistically significant differences in the positive attitudes of SMEs between Czech entrepreneurs and entrepreneurs from Slovakia, Poland, Hungary and Ukraine ( $p$-value $=0.0076 / 0.0003 / 0.0011 /<0.0001)$. Czech entrepreneurs significantly agree with the statement of ST1 more than entrepreneurs from SR and PL. On the contrary, they agree significantly less with the ST1 than entrepreneurs from HU and UA. 
INTERNATIONAL JOURNAL OF ENTREPRENEURIAL KNOWLEDGE

Issue 2, volume 8, ISSN 2336-2960 (Online)

www.ijek.org

Table 1 Perception of the intensity of legal risk

\begin{tabular}{|c|c|c|c|c|c|c|}
\hline STATEMENTS & \multicolumn{6}{|c|}{ COUNTRIES } \\
\hline $\begin{array}{l}\text { ST1: I consider the } \\
\text { legal risk- } \\
\text { appropriate and it } \\
\text { does not harm our } \\
\text { (my) business }\end{array}$ & $\begin{array}{c}\text { Czech } \\
\text { Republic } \\
\text { (CR) } \\
454\end{array}$ & $\begin{array}{c}\text { Slovak } \\
\text { republic } \\
(\mathrm{SR}) \\
368\end{array}$ & $\begin{array}{c}\text { Poland } \\
\text { (PL) } \\
364\end{array}$ & $\begin{array}{c}\text { Hungary } \\
\text { (HU) } \\
399\end{array}$ & $\begin{array}{c}\text { Ukraine } \\
\text { (UA) } \\
350\end{array}$ & $\begin{array}{c}\text { Z-score/ } \\
\mathrm{p} \text {-value } \\
\mathrm{CR} / \mathrm{SR} \\
\mathrm{CR} / \mathrm{PL} \\
\mathrm{CR} / \mathrm{HU} \\
\mathrm{CR} / \mathrm{UA}\end{array}$ \\
\hline 1. Strongly agree & 45 & 31 & 39 & 68 & 165 & $\begin{array}{c}2,6683 / \\
0.0076\end{array}$ \\
\hline 2. Agree & 166 & 106 & 85 & 162 & 120 & $\begin{array}{l}3.587 / \\
0.0003\end{array}$ \\
\hline $1+2$ total $\%$, count & $46.47 / 211$ & $37.23 / 137$ & $34.06 / 124$ & $57.64 / 230$ & $81.43 / 285$ & $\begin{array}{c}-3.2569 / \\
0.0011\end{array}$ \\
\hline $\begin{array}{l}\text { 3. Neither agree } \\
\text { nor disagree }\end{array}$ & 131 & 104 & 88 & 114 & 38 & $\begin{array}{l}-10.107 / \\
p<0.0001\end{array}$ \\
\hline 4. Disagree & 71 & 99 & 92 & 45 & 21 & \\
\hline 5. Strongly disagree & 41 & 28 & 60 & 10 & 6 & \\
\hline $\begin{array}{l}\text { Chi-square: } \\
\text { p- value }\end{array}$ & $\begin{array}{c}\mathrm{CR} / \mathrm{SR} \\
17.1678 / \\
0.0018\end{array}$ & $\begin{array}{c}\mathrm{CR} / \mathrm{PL} \\
31.7731 / \\
\mathrm{p}<0.0001\end{array}$ & $\begin{array}{c}\mathrm{CR} / \mathrm{HU} \\
27.1471 / \\
\mathrm{p}<0.0001\end{array}$ & $\begin{array}{c}\mathrm{CR} / \mathrm{UA} \\
169.7732 / \\
\mathrm{p}<0.0001\end{array}$ & & \\
\hline
\end{tabular}

(Source: own data collection)

The agreement rate with the ST2 ranges from 34.24\% (Slovak Republic: lowest agreement rate) to $77.14 \%$ (Ukraine: highest agreement rate). The average rate of agreement with the ST2 statement was 45.56\%. This result does not confirm the previous research made by Bondareva \& Zatrochová (2014). They conclude that the smooth operations of the legal risk framework in the business environment provides a stable and successful place for SME. The lowest agreement rate in case of Slovak Republic supports the same results as a research made by Belas et al. (2020). They found out that there is a higher skepticism among Slovak entrepreneurs in comparison with Czech ones.

Based on the Chi-square method, we found that the responses of Czech entrepreneurs differ from the attitudes of Slovak, Hungarian and Ukrainian entrepreneurs (p-value $=0.0083 /<0.0001 /<0.0001$ ). On the contrary, the structure of the answers of Czech and Polish entrepreneurs is comparable ( $\mathrm{p}$-value $=$ $0.291)$.

The test values of the Z-score confirmed that there are statistically significant differences in the positive attitudes of SMEs between Czech entrepreneurs and entrepreneurs from Ukraine ( $\mathrm{p}$-value $=<0.0001$ ). Czech entrepreneurs agree significantly less with ST2 than entrepreneurs from UA. In this regard, it is possible to suppose that the greater perception and agreement regarding the influence of frequent legislative changes on business could derive from different conditions of SMEs in Ukraine compared to those in other countries. Indeed, they are characterized by insufficient performance, short-term investment orientation in trade, a high level of informal economy and variable regulatory legislations (Shutyak \& Van Caillie, 2015). In this context, changes in laws define a new legislative base of this country that supports the small business to tackle crises and develop conditions for effective market reforms in Ukraine. 
INTERNATIONAL JOURNAL OF ENTREPRENEURIAL KNOWLEDGE Issue 2, volume 8, ISSN 2336-2960 (Online)

www.ijek.org

Table 2 Perception of legislative changes and their impact on entrepreneurship

\begin{tabular}{|c|c|c|c|c|c|c|}
\hline STATEMENTS & \multicolumn{6}{|c|}{ COUNTRIES } \\
\hline $\begin{array}{l}\text { ST2: Business is } \\
\text { affected by } \\
\text { frequent } \\
\text { legislative } \\
\text { changes, but it } \\
\text { has no negative } \\
\text { impact on our } \\
\text { (my) business }\end{array}$ & $\begin{array}{l}\text { Czech } \\
\text { Republic } \\
\text { (CR) } \\
454\end{array}$ & $\begin{array}{l}\text { Slovak } \\
\text { Republic } \\
\text { (SR) } \\
368\end{array}$ & $\begin{array}{l}\text { Poland } \\
\text { (PL) } \\
364\end{array}$ & $\begin{array}{l}\text { Hungary } \\
\text { (HU) } \\
399\end{array}$ & $\begin{array}{l}\text { Ukraine } \\
\text { (UA) } \\
350\end{array}$ & $\begin{array}{l}\text { Z-score/ } \\
\text { p-value } \\
\text { CR/SR } \\
\text { CR/PL } \\
\text { CR/HU } \\
\text { CR/UA }\end{array}$ \\
\hline 1. Strongly agree & 64 & 44 & 44 & 36 & 153 & $\begin{array}{l}1.6589 / \\
0.0969\end{array}$ \\
\hline 2. Agree & 117 & 82 & 86 & 127 & 117 & $\begin{array}{l}1.2162 / \\
0.2225\end{array}$ \\
\hline $\begin{array}{l}1+2 \text { total } \%, \\
\text { count }\end{array}$ & $39.87 / 181$ & $34.24 / 126$ & $35.71 / 130$ & $40.85 / 163$ & $77.14 / 270$ & $\begin{array}{l}-0.2924 / \\
0.7718\end{array}$ \\
\hline $\begin{array}{l}\text { 3. Neither agree } \\
\text { nor disagree }\end{array}$ & 123 & 94 & 87 & 133 & 46 & $\begin{array}{l}-10.559 / \\
p<0.0001\end{array}$ \\
\hline 4. Disagree & 76 & 100 & 71 & 88 & 24 & \\
\hline $\begin{array}{ll}5 . & \text { Strongly } \\
\text { disagree }\end{array}$ & 74 & 48 & 76 & 15 & 10 & \\
\hline $\begin{array}{l}\text { Chi-square: } \\
\text { p- value }\end{array}$ & $\begin{array}{l}\text { CR/SR } \\
13.7012 \\
0.0083\end{array}$ & $\begin{array}{l}\mathbf{C R} / \mathbf{P L} \\
4.9637 \\
0.2910\end{array}$ & $\begin{array}{l}\text { CR/HU } \\
45.2728 \\
p<0.0001\end{array}$ & $\begin{array}{l}\text { CR/UA } \\
136.2135 / \\
p<0.0001\end{array}$ & & \\
\hline
\end{tabular}

(Source: own data collection)

Table 3 Perception of the quantity of legislative norms

\begin{tabular}{|c|c|c|c|c|c|c|}
\hline STATEMENTS & \multicolumn{6}{|c|}{ COUNTRIES } \\
\hline $\begin{array}{l}\text { ST3: I do not } \\
\text { consider } \\
\text { business } \\
\text { environment to be } \\
\text { 'over-regulated' }\end{array}$ & $\begin{array}{l}\text { Czech } \\
\text { Republic } \\
\text { (CR) } \\
454\end{array}$ & $\begin{array}{l}\text { Slovak } \\
\text { Republic } \\
\text { (SR) } \\
368\end{array}$ & $\begin{array}{l}\text { Poland } \\
\text { (PL) } \\
364\end{array}$ & $\begin{array}{l}\text { Hungary } \\
\text { (HU) } \\
399\end{array}$ & $\begin{array}{l}\text { Ukraine } \\
\text { (UA) } \\
350\end{array}$ & $\begin{array}{l}\text { Z-score/ } \\
\text { p-value } \\
\text { CR/SR } \\
\text { CR/PL } \\
\text { CR/HU } \\
\text { CR/UA }\end{array}$ \\
\hline 1. Strongly agree & 50 & 33 & 31 & 28 & 151 & $\begin{array}{l}-0.2231 / \\
0.8259\end{array}$ \\
\hline 2. Agree & 69 & 66 & 57 & 133 & 126 & $\begin{array}{l}0.6655 \quad / \\
0.5029\end{array}$ \\
\hline $\begin{array}{l}1+2 \text { total } \%, \\
\text { count }\end{array}$ & $26.21 / 119$ & $26.90 / 99$ & $24.18 / 88$ & $40.35 / 161$ & $79.14 / 277$ & $\begin{array}{l}-4.388 \quad / \\
\text { p }<0.0001\end{array}$ \\
\hline $\begin{array}{l}\text { 3. Neither agree } \\
\text { nor disagree }\end{array}$ & 106 & 96 & 113 & 119 & 44 & $\begin{array}{l}-14.8842 / \\
p<0.0001\end{array}$ \\
\hline 4. Disagree & 121 & 106 & 92 & 90 & 18 & \\
\hline
\end{tabular}


INTERNATIONAL JOURNAL OF ENTREPRENEURIAL KNOWLEDGE

Issue 2, volume 8, ISSN 2336-2960 (Online)

www.ijek.org

\begin{tabular}{||l|l|l|l|l|l|l||}
\hline \hline 5. Strongly & 108 & 67 & 71 & 29 & 11 & \\
disagree & & & & & & \\
\hline Chi-square: & CR/SR & CR/PL & CR/HU & CR/UA & & \\
& $5.7054 \quad /$ & $7.6097 \quad /$ & $\mathbf{7 4 . 1 0 4 5} \quad /$ & $\mathbf{2 3 8 . 9 7 6 3 ~ / ~}$ \\
$\mathbf{p}<\mathbf{0 . 0 0 0 1}$ & 0.2223 & 0.1069 & $\mathbf{0 . 0 0 0 1}$ & & \\
\hline
\end{tabular}

(Source: own data collection)

The agreement rate with the ST3 statement ranges from $24.18 \%$ (Poland: lowest agreement rate) to $79.14 \%$ (Ukraine: highest agreement rate). The average rate of agreement with ST3 was 39.36\%. This result is different from the statement of Kim \& Vonortas (2014). They concluded that SMEs usually find business environment not to be over-regulated in terms of a legal risk.

Based on the use of the Chi-square method, we found that the responses of Czech entrepreneurs differ from the attitudes of Hungarian and Ukrainian entrepreneurs (p-value <0.0001 / <0.0001). On the contrary, the structure of responses between Czech and Slovak, and Czech and Polish entrepreneurs was comparable $(\mathrm{p}$-value $=0.2223 / 0.1069)$.

Table 4 Understanding the legal aspects of business

\begin{tabular}{|c|c|c|c|c|c|c|}
\hline \multirow{2}{*}{$\begin{array}{lr}\text { STATEMENTS } \\
\text { ST4: } \\
\text { understand } \\
\text { essential the } \\
\text { aspects of dogal } \\
\text { business. }\end{array}$} & \multicolumn{6}{|c|}{ COUNTRIES } \\
\hline & $\begin{array}{l}\text { Czech } \\
\text { Republic } \\
\text { (CR) } \\
454\end{array}$ & $\begin{array}{l}\text { Slovak } \\
\text { Republic } \\
\text { (SR) } \\
368\end{array}$ & $\begin{array}{l}\text { Poland } \\
\text { (PL) } \\
364\end{array}$ & $\begin{array}{l}\text { Hungary } \\
\text { (HU) } \\
399\end{array}$ & $\begin{array}{l}\text { Ukraine } \\
\text { (UA) } \\
350\end{array}$ & $\begin{array}{l}\text { Z-score/ } \\
\text { p-value } \\
\text { CR/SR } \\
\text { CR/PL } \\
\text { CR/HU } \\
\text { CR/UA }\end{array}$ \\
\hline 1. Strongly agree & 168 & 107 & 144 & 79 & 147 & $\begin{array}{l}-1.7957 / \\
0.0719\end{array}$ \\
\hline 2. Agree & 195 & 205 & 150 & 221 & 139 & $\begin{array}{l}-0.2907 / \\
0.7718 \\
\end{array}$ \\
\hline $\begin{array}{l}1+2 \text { total } \%, \\
\text { count }\end{array}$ & $79.95 / 363$ & $84.78 / 312$ & $80.77 / 294$ & $75.19 / 300$ & $81.71 / 286$ & $\begin{array}{l}1.6699 / \\
0.0949\end{array}$ \\
\hline $\begin{array}{l}\text { 3. Neither agree } \\
\text { nor disagree }\end{array}$ & 77 & 53 & 37 & 80 & 39 & $\begin{array}{l}-0.6266 / \\
0.5287\end{array}$ \\
\hline 4. Disagree & 10 & 2 & 20 & 15 & 15 & \\
\hline $\begin{array}{ll}5 . & \text { Strongly } \\
\text { disagree } & \\
\end{array}$ & 4 & 1 & 13 & 4 & 10 & \\
\hline $\begin{array}{l}\text { Chi-square: } \\
\text { p- value }\end{array}$ & $\begin{array}{l}\text { CR/SR } \\
16.5284 / \\
0.0024\end{array}$ & $\begin{array}{l}\text { CR/PL } \\
20.1911 \\
0.0005\end{array}$ & $\begin{array}{l}\text { CR/HU } \\
31.3351 \\
p<0.0001\end{array}$ & $\begin{array}{l}\text { CR/UA } \\
13.5835 \\
0.0087\end{array}$ & & \\
\hline
\end{tabular}

(Source: own data collection)

The test values of the $Z$-score confirmed that there are statistically significant differences in the positive attitudes of SMEs between Czech entrepreneurs and entrepreneurs from Hungary and Ukraine (p-value $<0.0001 /<0.0001)$. Czech entrepreneurs significantly agree with ST3 than entrepreneurs from HU and UA. A possible reason for the perception by managers of Czech Republic, which emphasize a greater quantity of legislative norms, could be connected to the role of the state which was predominantly dominant in all economic activities where integration of small and medium-sized enterprises led to the creation of large state-owned enterprises, completely liquidating any private sector (Makhija, 2003). 
INTERNATIONAL JOURNAL OF ENTREPRENEURIAL KNOWLEDGE

Issue 2, volume 8, ISSN 2336-2960 (Online)

www.ijek.org

Dobeš et al. (2017) confirms the similar results in case of SMEs in the Czech Republic. They found out that $78 \%$ of the addressed SMEs consider the business environment in the Czech Republic as overregulated.

The agreement rate with the ST4 statement ranges from $75.19 \%$ (Hungary: lowest agreement rate) to $81.14 \%$ (Slovak Republic: highest agreement rate). The average rate of agreement with ST4 was 80.48\%.

In this perspective, the awareness and the knowledge of the essential legal aspects of doing business is a key factor in ensuring the survival of small businesses. Petkovic et al. (2016) discovered that complicated legal procedures not acquired by management is one of the main obstacles to successful development of enterprises.

Thus, companies that perceive legal key factors and try to comply with the law are aware of the possible reputational risk that their business may incur if illegal conduct is adopted (Rayner, 2003). These companies, therefore, operate in harmony with the context and with the stakeholders, in order to obtain social legitimacy (Palazzo \& Scherer, 2006). Furthermore, not breaking the laws can be an element that forces companies to be in line with international standards relating to, for example, product performance, compliance with environmental standards and proper management of the working environment. In this sense, the regulatory pressure can be considered as a driver for the competitive growth of SMEs.

Based on the Chi-square method, we found that the responses of Czech entrepreneurs differ from the attitudes of Slovak, Polish, Hungarian and Ukrainian entrepreneurs (p-value $=0.0024 / 0.0005 /<0.0001$ / 0.0087).

\section{Table 5 Evaluation of hypotheses}

\begin{tabular}{||l|l|l||}
\hline \hline HYPOTHESIS & \multicolumn{1}{||}{} & RESULT \\
\hline H1 & $\begin{array}{l}\text { There are statistically significant differences in } \\
\text { perception of legal risk between entrepreneurs } \\
\text { from Czech SMEs and entrepreneurs from other } \\
\text { countries. }\end{array}$ & Confirmed \\
\hline H2 & $\begin{array}{l}\text { There are statistically significant differences in } \\
\text { perception of legislative changes and their impact } \\
\text { on SMEs between Czech entrepreneurs and } \\
\text { entrepreneurs from other countries. }\end{array}$ & Rejected \\
\hline H3 & $\begin{array}{l}\text { There are statistically significant differences in } \\
\text { perception of the quantity of regulation between } \\
\text { Czech entrepreneurs and entrepreneurs from } \\
\text { other countries. }\end{array}$ & Rejected \\
\hline H4 & $\begin{array}{l}\text { There are statistically significant differences in } \\
\text { understanding of the essential legal aspects of } \\
\text { doing business between Czech entrepreneurs and } \\
\text { entrepreneurs from other countries. }\end{array}$ & Confirmed \\
\hline
\end{tabular}

(Source: own data collection)

The test values of the Z-score confirmed that there are no statistically significant differences in the positive attitudes of SMEs between Czech entrepreneurs and entrepreneurs from Slovakia, Poland, Hungary and Ukraine ( $\mathrm{p}$-value $=0.0719 / 0.7718 / 0.0949 / 0.5287)$.

Table 5 shows the summary of evaluation of hypotheses set to fulfil the aim of the paper. 


\section{INTERNATIONAL JOURNAL OF ENTREPRENEURIAL KNOWLEDGE}

Issue 2, volume 8, ISSN 2336-2960 (Online)

www.ijek.org

\section{CONCLUSIONS}

The aim of the paper was to enrich the current scientific knowledges with a comparison of impacts of legal risk on the SMEs in selected countries. The empirical research was conducted in V4 countries and Ukraine. The results showed that there are statistically significant differences in consideration of legal risk in the case of SMEs in the selected countries.

The first hypothesis analysed differences in perception of legal risk. It was found that more than 50\% of SMEs consider the risk management of legal risk as appropriate and do not think that it harms their business. In Poland, approval of the statement is the lowest from all the selected countries (31.46\%). On the contrary, $83 \%$ of the Ukrainian companies think that they manage the legal risk appropriately and it has no threat to their business. The structure of Czech responses is different from Slovak, Polish, Hungarian and Ukrainian responses. Czech entrepreneurs agree with this statement much more than entrepreneurs from Slovakia and Poland and much less than entrepreneurs from Hungary and Ukraine.

According the second hypothesis, we can conclude that 34\% of SMEs from Slovakia think that their business is affected by frequent legislative changes, but there is no negative impact on their business. It is the lowest percentage of consent from all countries. The highest rate of consent was noticed in the case of Ukrainian SMEs (77\%). There are differences in responses in Czech SMEs in comparison with Slovak, Hungarian and Ukrainian SMEs. The Polish responses are comparable with Czech opinions.

The third hypothesis analysed a consideration of over-regulation of the business environment. It can be concluded that 39\% of SMEs do not consider the business environment as over-regulated. The lowest rate of consent was noticed in the case of SMEs from Poland $(24.18 \%)$ with the highest in the case of Ukraine (79.14\%). There are differences in responses in Czech SMEs in comparison with Slovak, Hungarian and Ukrainian SMEs. The responses of SMEs from Poland are comparable with the opinions amongst Czech SMEs.

According to the fourth hypothesis, it can be stated that $80 \%$ of SMEs understand the essential legal aspects of doing business. The structure of Czech responses is different from Slovak, Polish, Hungarian and Ukrainian responses.

The results can be interesting for the government of each state for improving the business environment. The attention of academics and potential readers from the SME segment around the world can be attracted by these results. Moreover, findings can provide useful information to the Chief Financial Officers (CFOs) of SMEs analysed on how to improve the management of legal risk within firms. In this regard, it must be pointed out that organizations need to appropriately adopt an integrated approach to risk management (Hudáková \& Dvorský, 2018) which refers to the correct and systematic management of all business risks, such as operational risk, financial risk, security and fraud risk, market risk, reputational risk, etc. and it can help to extend SMEs' internationalization and competitiveness.

However, this study has some limitations. Firstly, the research analyses SMEs in the Visegrad Group and Ukraine. Therefore, the results cannot be generalized. Secondly, we cannot be sure that the questionnaire was filled out by responsible employees. Finally, there can be some misunderstanding in the questionnaire due to the translation from English to different languages. The future research should evaluate the consistency and reliability of risk management in the case of legal risk and other business risks as well. Moreover, this study can be viewed as a starting point for future research on a larger sample that includes other world countries which do not have a comparable business environment. Future cross-company comparisons could highlight greater insights into this field of study. 
INTERNATIONAL JOURNAL OF ENTREPRENEURIAL KNOWLEDGE

Issue 2, volume 8, ISSN 2336-2960 (Online)

www.ijek.org

\section{REFERENCES}

Abimbola, T., \& Vallaster, C. (2007). Brand, organisational identity and reputation in SMEs: an overview. Qualitative market research: An International Journal, 10(4), 341 - 348.

Antoniuk, L., Britchenko, I., Polishchuk, Y., Rudyk, N., Sybirianska, Y., \& Machashchik, P. (2018). Code of ethics for SMEs: Substantiating the necessity and willingness to implement in Ukraine. Problems and Perspectives in Management, 16(3), 150-162. https://doi.og/10.21511/ppm.16(3).2018.12

Bàcsi, J., \& Herczeg, I. (2014). Local currency as a tool of risk management in the small and medium enterprise sector. Roczniki (Annals), 3. 18-23. https://doi.org/10.22004/ag.econ.201814

Bagley, C. E. (2008). Winning legally: The value of legal astuteness. Academy of Management Review, 33(2), 378-390. https://doi.org/10.5465/AMR.2008.31193254

Belas, J., Gavurova, B., Cepel, M., \& Kubak, M. (2020). Evaluation of economic potential of business environment development by comparing sector differences: perspective of SMEs in the Czech Republic and Slovakia. Oeconomia Copernicana, 11(1), 135-159. https://doi.org/10.24136/oc.2020.006

Belas, J., Strnad, Z., Gavurova, B., \& Cepel, M. (2019). Business environment quality factors researchsme management's platform. [Badanie jakości środowiska biznesowego-platforma zarządzania mśp] Polish Journal of Management Studies, 20(1), 64-77. https://doi.org/10.17512/pjms.2019.20.1.06

Bondareva, I., \& Zatrochová, M. (2014). Financial Support for the Development of SMEs in the Slovak Republic. Procedia - Social and Behavioral Sciences, 110, 541-548. https://doi.org/10.1016/j.sbspro.2013.12.898

Cepel, M., Belas, J., Rozsa, Z., \& Strnad, Z. (2019). Selected economic factors of the quality of business environment. Journal of International Studies, 12(2), 228-240. doi:10.14254/2071-8330.2019/12$2 / 14$

Cook, P., \& Nixson, F. (2000). Finance and small and medium-Sized enterprise development. Finance and Development Research Programme, 14, 1-28. https://doi.org/10.1016/S0148-2963(03)00070-5

Deligonul, S. Z. (2020). Multinational country risk: Exposure to asset holding risk and operating risk in international business. Journal of World Business, 55(2), 101041. https://doi.org/10.1016/j.jwb.2019.101041

Dobeš, K., Kot, S., Kramoliš, J., Sopková, G. (2017). The Perception of Governmental Support in The Context of Competitiveness of SMEs in the Czech Republic. Journal of Competitiveness, 9 (3), 34-50. https://doi.org/10.7441/joc.2017.03.03

Dvorský, J., Petráková, Z., \& Fialová, V. (2020). Perception of business risk by entrepreneurs according to experience with the business failure. International Journal of Entrepreneurial Knowledge, 8(1), 76-88. https://doi.org/10.37335/ijek.v8i1.104

Falkner, E. M., \& Hiebl, M. R. (2015). Risk management in SMEs: a systematic review of available evidence. The Journal of Risk Finance, 16 (2), 122-144.

Faisal, A. M., \& Singh, K. S. (2019). Implementing Lean Technique by using Value Stream Mapping ( VSM ) in a Labour- intensive Small and Medium Enterprise ( SME ): Case Study of Goods Manufacturing Company. 9 (February), 567-572.

Ferreira de Araújo Lima, P., Crema, M., \& Verbano, C. (2020). Risk management in SMEs: A systematic literature review and future directions. European Management Journal, 38(1), 78-94. https://doi.org/10.1016/j.emj.2019.06.005

Gwizdała, J. P. (2017). The Financing of Small and Medium-Sized Enterprises with the EU Structural Funds in Poland Between 2014 and 2020. International Journal of Synergy and Research, 6, 43-55. https://doi.org/10.17951/ijsr.2017.6.43

Ghența, M., \& Matei, A. (2018). Smes and the circular economy: From policy to difficulties encountered during implementation. Amfiteatru Economic, 20(48), 294-309. https://doi.org/10.24818/EA/2018/48/294

Grau, A., \& Reig, A. (2020). Operating leverage and profitability of SMEs: agri-food industry in Europe. Small Business Economics. https://doi.org/10.1007/s11187-019-00294-y 


\section{INTERNATIONAL JOURNAL OF ENTREPRENEURIAL KNOWLEDGE}

Issue 2, volume 8, ISSN 2336-2960 (Online)

www.ijek.org

Hudáková, M., \& Dvorský, J. (2018). Assessing the risks and their sources in dependence on the rate of implementing the risk management process in the SMEs. Equilibrium. Quarterly Journal of Economics and Economic Policy, 13 (3), 543-567. https://doi.org/10.24136/eq.2018.027

Karpak, B., \& Topçu, Y. I. (2010). Small medium manufacturing enterprises in Turkey: An analytic network process framework for prioritizing factors affecting success. International Journal of Production Economics, 125(1), 60-70. https://doi.org/10.1016/j.ijpe.2010.01.001

Kim, Y., \& Vonortas, N. S. (2014). Managing risk in the formative years: Evidence from young enterprises in Europe. Technovation, 34(8), 454-465. https://doi.org/10.1016/j.technovation.2014.05.004

Kotaskova, A., \& Rozsa, Z. (2018). The impact of selected factors on the quality of business environment assessment in the Czech Republic and the Slovak Republic. International Journal of Entrepreneurial Knowledge, 6(2), 71-80. https://doi.org/10.2478/IJEK-2018-0015

Kwaku Amoah, S. (2018). The Role of Small and Medium Enterprises (SMEs) to Employment in Ghana. International Journal of Business and Economics Research, 7(5), 151. https://doi.org/10.11648/j.ijber.20180705.14

Makhija, M. (2003). Comparing the resource-based and market-based views of the firm: empirical evidence from Czech privatization. Strategic Management Journal, 24(5), 433-451.

Martinez-Conesa, I., Soto-Acosta, P., \& Palacios-Manzano, M. (2017). Corporate social responsibility and its effect on innovation and firm performance: An empirical research in SMEs. Journal of Cleaner Production, 142, 2374-2383. https://doi.org/10.1016/j.jclepro.2016.11.038

Mura, L., \& Ključnikov, A. (2018). Small businesses in rural tourism and agro tourism: study from Slovakia. Economics \& Sociology, 11(3), 286-300. https://doi.org/10.14254/2071-789X.2018/11$3 / 17$

Palacios-Marqués, D., Merigó, J. M., \& Soto-Acosta, P. (2015). Online social networks as an enabler of innovation in organizations. Management Decision, 53(9), 1906-1920. https://doi.org/10.1108/MD06-2014-0406

Pasnicu, D. (2018). Supporting SMEs in creating jobs. Journal of Economic Development, Environment and People, 7(1), 15. https://doi.org/10.26458/jedep.v7i1.575

Palazzo G., \& Scherer, A. (2006). Corporate legitimacy as deliberation: a communicative framework. Journal of Business Ethics, 66 (1), 71-88.

Petković, S., Jäger, C., Sašić, B. (2016). Challenges of small and medium sized companies at early stage of development: Insights from Bosnia and Herzegovina. Management: Journal of Contemporary Management Issues, 21(2), 45-76.

Pereira, L., Tenera, A., Bispo, J., \& Wemans, J. (2015). A risk diagnosing methodology web-based platform for micro, small and medium businesses: Remarks and enhancements. Communications in Computer and Information Science, 454(February), 340-356. https://doi.org/10.1007/978-3-66246549-3_22

Rayner J. (2003). Managing Reputational Risk. Curbing Threats, Leveraging Opportunities. Hoboken, NJ: Wiley.

Reverte, C. (2015). The new Spanish corporate social responsibility strategy 2014-2020: A crucial step forward with new challenges ahead. Journal of Cleaner Production, 91(2015), 327-336. https://doi.org/10.1016/j.jclepro.2014.12.041

Ruchkina, G., Melnichuk, M., Frumina, S., \& Mentel, G. (2017). Small and medium enterprises in the context of regional development and innovations. Journal of International Studies, 10(4), 259-271. https://doi.org/10.14254/2071-8330.2017/10-4/20

Sarantakos, S. (2005). Social Research, 3rd ed., Palgrave Macmillan, Hampshire.

Shanmugam, R. (2010). Books on risk analysis are reviewed. Journal of Statistical Computation and Simulation, 80(8), 949-950. https://doi.org/10.1080/00949650802288841

Shutyak, Y., \& Van Caillie, D. (2015). The Role of government in path-dependent development of SME sector in Ukraine. Journal of East-West Business, 21(1), 67-90.

Virglerova, Z., Dobes, K., \& Vojtovic, S. (2016). The perception of the state's influence on its business environment in the SMEs from Czech Republic. Administratie Si Management Public, 2016(26), 78 96. 
INTERNATIONAL JOURNAL OF ENTREPRENEURIAL KNOWLEDGE

Issue 2, volume 8, ISSN 2336-2960 (Online)

www.ijek.org

Wang, W. Y. C., Pauleen, D. J., \& Zhang, T. (2016). How social media applications affect B2B communication and improve business performance in SMEs. Industrial Marketing Management, 54, 4-14. https://doi.org/10.1016/j.indmarman.2015.12.004

Watkins, J. A. (2012). A literature review of small and medium enterprises (SME) risk management practices in South Africa. African Journal of Business Management, 6(21), 6324-6330.

Wysokinska Z. (2017). Effects of Poland's Pro-Export Policy Implementation in the Context of the Plan for Responsible Development - a Preliminary Comparative Assessment. Comparative Economic Research, 20 (4), https://doi.org/201710.1515/cer-2017- 0030

Zhao, S., \& Zeng, M. (2014). Theory of SMEs financial risk prevention and control. Proceedings of the 2014 International Conference on Education, Management and Computing Technology, 514-517. https://doi.org/10.2991/icemct-14.2014.126

\section{BRIEF DESCRIPTION OF AUTHOR/AUTHORS:}

\section{Zuzana Virglerová, Ph.D.}

Researcher, Center for Applied Economic Research, Faculty of Management and Economics, Tomas Bata University in Zlín, Mostní 5139, Zlin 760 01, Czech Republic,

E-mail: virglerova@utb.cz

Webpage: https:// fame.utb.cz/en/contacts/ing-zuzana-virglerova-ph-d-2/

ORCID: 0000-0002-7957-9216

Area of interest: business risks, SMEs, business environment.

\section{Francesca Conte, Ph.D.}

Lecturer in e-commerce and cultural marketing, University of Salerno, Department of Political and Communication Sciences, Via Giovanni Paolo II, 132 - 84084 Fisciano (SA), Italy

Email: fconte@unisa.it

Webpage: https://docenti.unisa.it/024895/home

ORCID: 0000-0001-6822-1502

Area of interest: sustainability, corporate communication, corporate reputation.

\section{John Amoah}

PhD Student, Faculty of Management and Economics, Tomas Bata University in Zlín, Mostní 5139, Zlin 760 01, Czech Republic

Email: jamoah@utb.cz

ORCID: 0000-0002-3558-2077

Area of interest: financial performance of SMEs, banking industry, entrepreneurship

\section{Maria Rita Massaro PhD}

Lecturer in Marketing, University of Westminster, School of Management and Marketing, 35, Marylebone Road, NW1 5LS, London

Email: r.massaro@westminster.ac.uk

Webpage: https://www.westminster.ac.uk/about-us/our-people/directory/massaro-rita Area of interest: entrepreneurship, innovation, brand management, destination branding. 